\title{
EXCRETION OF HYDROXYPROLINE IN PATIENTS WITH RHEUMATIC AND NON-RHEUMATIC DISEASES ${ }^{1}$
}

\author{
By MORRIS ZIFF,2 ANDRE KIBRICK, ELLIS DRESNER, AND \\ H. JOEL GRIBETZ \\ (From the Department of Medicine and the Study Group on Rheumatic Diseases, New York \\ University College of Medicine, New York, N. Y.)
}

(Submitted for publication December 29, 1955; accepted January 30, 1956)

The amino acid hydroxyproline constitutes approximately 13 per cent of collagen $(1,2)$, and 1 to 2 per cent of elastin (2). It is present in no other protein of the body. For this reason, the determination of hydroxyproline has been utilized for the estimation of collagen in various animal tissues (3), and in the fibrinoid material of the subcutaneous nodule of rheumatoid arthritis (4).

It is, at the present time, not clear whether in the diseases of the connective tissue, or "collagen diseases," significant alteration and degradation of the protein collagen occurs. The light microscope studies of Klinge (5) and of Bahrmann (6), who observed swelling of collagen in tissue sections of lesions from patients with rheumatic and other diseases, suggested that these changes do occur. Others (7-9) have shown in addition that swelling and focal degeneration of collagen fibers is a common and striking effect of anaphylactoid hypersensitivity reactions.

Using the electron microscope, however, Gross (10) and Gale (11) did not find abnormal fibers in material from lesions of rheumatoid arthritis, rheumatic fever, disseminated lupus erythematosus, and scleroderma. Though Wolpers (12) did observe fibrils lacking cross striations in necrotic areas of old rheumatoid nodules, the fibers were normal in non-necrotic areas and in samples of collagen obtained from Arthus lesions. When cross sections of rheumatoid nodules were submitted to careful X-ray diffraction study by Kellgren, Ball, Astbury, Reed, and Beighton (13) normal collagen patterns were seen where collagen was present in the section, and the pattern of an amorphous material where fibrinoid was present.

1 This investigation was supported (in part) by grant No. H1431 (C) from the National Heart Institute, National Institutes of Health, U. S. Public Health Service, and by a grant from the Masonic Foundation for Medical Research and Human Welfare.

2 Senior Fellow, Arthritis and Rheumatism Foundation.
In contrast to the preceding workers, Rich, Voisin, and Bang (14) did observe altered fibrils in a small percentage of samples of tissue from Arthus lesions examined with the electron microscope.

The fibrinoid material of the subcutaneous nodule of rheumatoid arthritis has recently been extracted (4) and found to contain negligible amounts of hydroxyproline, indicating that, in all probability, it does not contain degraded collagen and arises from other components of the connective tissue.

Because hydroxyproline is present almost entirely in collagen, it was felt that if there were a significant deviation from normal in the metabolism of collagen or an increase in degradation of this protein in patients with collagen diseases, these changes might be reflected by increased levels of excretion of this amino acid in urine.

\section{METHODS}

Sixty-four patients were studied, of whom 48 were adults ranging in age from 17 to 74 , and 16 were children ranging in age from 5 to 14 . Twenty-four of the adults were men and 22 women; all but one of the children were boys. Among the adults, 8 were normal individuals and 16 had rheumatoid arthritis. Eight had one of the collagen diseases, i.e., 2 had disseminated scleroderma; 1, isolated scleroderma; 2, disseminated lupus erythematosus; 1, dermatomyositis; and 2, acute rheumatic fever. Sixteen had one of a group of miscellaneous diseases; these included 4 patients with resolving pneumonia, and one patient each with the following conditions: multiple sclerosis, coronary heart disease, acromegaly, pelvic inflammatory disease, pulmonary fibrosis, Hodgkins disease, possible G. I. neoplasm, acute gastritis, post-cholecystectomy syndrome, acute gout, fracture of the tibia, and malunion of the femur. Among the children, three were normal individuals; two had congenital heart disease; 3 were convalescing from attacks of rheumatic fever ; 2 from pulmonary infections; 1 from typhoid fever ; and 1 from an attack of gonococcal arthritis. One child had active rheumatic fever, one schistosomiasis, and one minimal pulmonary tuberculosis.

The patients were hospitalized on special wards, and 
TABLE I

Total hydroxyproline concentration of urine by methods of Wiss, Keston, Udenfriend, and Levy, and Troll and Cannan

\begin{tabular}{|c|c|c|c|c|c|c|}
\hline Patient & Sex & Age & Diagnosis & $\begin{array}{l}\text { Wiss } \\
(\gamma / m l .)\end{array}$ & $\begin{array}{l}\text { Keston. } \\
\text { Udenfriend, } \\
\text { and Levy } \\
(\gamma / m l .)\end{array}$ & $\begin{array}{c}\text { Troll and } \\
\text { Cannan } \\
(\gamma / m l .)\end{array}$ \\
\hline W. K. & M & 5 & Normal & 109.0 & 105.0 & \\
\hline J.S. & $F$ & 32 & Normal & 37.5 & 38.6 & \\
\hline L. S. & $\mathrm{F}$ & 23 & Normal & 25.6 & 23.8 & \\
\hline R. C. & M & 30 & Rheumatic fever & 27.1 & 25.6 & \\
\hline F. P. & M & 11 & $\begin{array}{c}\text { Rheumatic fever } \\
\text { (convalescent) }\end{array}$ & 57.8 & & 62.2 \\
\hline F. R. & M & 8 & $\begin{array}{l}\text { Rheumatic fever } \\
\text { (convalescent) }\end{array}$ & 58.3 & & 56.4 \\
\hline M. O. & $\mathrm{F}$ & 35 & $\begin{array}{l}\text { Pneumonia } \\
\text { (convalescent) }\end{array}$ & 20.0 & & 21.8 \\
\hline
\end{tabular}

fed a low hydroxyproline diet. This was achieved by restriction as far as possible of foods containing collagen or gelatin. The diet contained no meat, fish, jello, candy or ice cream, and provided approximately 2,100 calories daily. It contained 70 grams of protein, 220 to 250 grams of carbohydrate, and 90 grams of fat, in the form of milk, cheese, eggs, vegetables, bread and butter, and juices.

Twenty-four hour urine specimens were collected. To check adequacy of collection, total creatinine was determined, and in the case of the children, both creatinine and creatine were determined (15).

Free and total hydroxyproline were determined by the method of Wiss (16). The values presented for individual patients are average values, in most cases of three separate 24-hour collections.

Free hydroxyproline in urine: Eight $\mathrm{ml}$. of filtered urine, or if appropriate a smaller volume containing 2 to $6 \gamma$ of hydroxyproline were analyzed directly.

Total hydroxyproline in urine: To $30 \mathrm{ml}$. of urine were added $30 \mathrm{ml}$. of concentrated hydrochloric acid and the resulting solution was autoclaved for three hours at 50 lbs. pressure. The solution was cooled, adjusted to a volume of $60 \mathrm{ml}$, and filtered. Fifty $\mathrm{ml}$. of the filtrate were evaporated to dryness in racuo and the residue was taken up in $25 \mathrm{ml}$. of water. An aliquot of this solution was diluted so that $8 \mathrm{ml}$. contained from 2 to $6 \gamma$ of hydroxyproline. This was neutralized with sodium hydroxide, and analyzed according to Wiss.

In order to test the accuracy of the Wiss colorimetric method, simultaneous analyses were done for total hydroxyproline on four separate urine samples by the radioactive isotopic derivative method of Keston, Udenfriend, and Levy (17) and on three other urine samples by a modification (18) of the method of Troll and Cannan (19) for hydroxyproline.

To analyze the urine by the isotopic derivative technique, $5 \mathrm{ml}$. of urine and $5 \mathrm{ml}$. of $12 \mathrm{~N}$ hydrochloric acid were heated together in sealed tubes at $50 \mathrm{lbs}$. pressure for three hours. Five $\mathrm{ml}$. of the hydrolysate was brought to dryness and hydrochloric acid was removed by repeated distillation in vacuo. The residue was then taken up in $1 \mathrm{ml}$. of water, and $0.1 \mathrm{ml}$. was placed in a Folin-Wu tube. Ammonia was removed by addition of $0.1 \mathrm{ml}$. of $2 \mathrm{M}$ sodium carbonate solution, boiling for ten minutes with attendant agitation using a mechanical vibrator. The pipsyl derivative was then prepared by addition of $30 \mathrm{mg}$. of paraiodophenyl sulfonyl chloride (pipsyl chlo-

TABLE II

Daily excretion of hydroxyproline in normal adults

\begin{tabular}{|c|c|c|c|c|c|c|c|}
\hline Patient & Age & $\begin{array}{l}\text { No. days } \\
\text { averaged }\end{array}$ & $\begin{array}{c}\text { Free } \\
\text { hydroxy- } \\
\text { proline } \\
(m g .)\end{array}$ & $\begin{array}{c}\text { Total } \\
\text { hydroxy- } \\
\text { proline } \\
(\mathrm{mg} .)\end{array}$ & $\begin{array}{l}\text { Total } \\
\text { amino } \\
\text { acid } \\
(g .)\end{array}$ & $\begin{array}{c}\% \text { Total } \\
\text { amino acid } \\
\text { as free } \\
\text { hydroxyproline }\end{array}$ & $\begin{array}{c}\% \text { Total } \\
\text { amino acid } \\
\text { as hydroxy- } \\
\text { proline }\end{array}$ \\
\hline 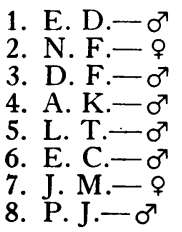 & $\begin{array}{l}32 \\
24 \\
24 \\
23 \\
23 \\
22 \\
35 \\
74\end{array}$ & $\begin{array}{l}4 \\
4 \\
4 \\
4 \\
4 \\
4 \\
4 \\
2\end{array}$ & $\begin{array}{l}0.41 \\
0.43 \\
0.69 \\
0.56 \\
0.79 \\
0.77 \\
0.46 \\
0.26\end{array}$ & $\begin{array}{l}20.2 \\
17.5 \\
23.3 \\
30.5 \\
29.2 \\
33.0 \\
14.9 \\
15.8\end{array}$ & $\begin{array}{l}2.15 \\
1.47 \\
1.51 \\
1.99 \\
1.61 \\
1.56 \\
1.59 \\
1.56\end{array}$ & $\begin{array}{l}0.019 \\
0.029 \\
0.046 \\
0.028 \\
0.049 \\
0.049 \\
0.029 \\
0.017\end{array}$ & $\begin{array}{l}0.95 \\
1.19 \\
1.55 \\
1.53 \\
1.81 \\
2.12 \\
0.94 \\
1.02\end{array}$ \\
\hline Median & & & 0.51 & 21.8 & 1.58 & 0.029 & 1.36 \\
\hline Range & & & $\begin{array}{l}0.26 \\
0.79\end{array}$ & $\begin{array}{l}14.9- \\
33.0\end{array}$ & $\begin{array}{l}1.47- \\
2.15\end{array}$ & $\begin{array}{l}0.017- \\
0.049\end{array}$ & $\begin{array}{l}0.94- \\
2.12\end{array}$ \\
\hline
\end{tabular}


TABLE III

Daily excretion of total hydroxyproline in five groups of individuals *

\begin{tabular}{|c|c|c|c|c|c|c|c|}
\hline \multirow[b]{3}{*}{ Group } & \multirow[b]{3}{*}{ No. } & \multirow[b]{3}{*}{ Sex } & \multirow[b]{3}{*}{ Age } & \multicolumn{4}{|c|}{ Total hydroxyproline } \\
\hline & & & & \multicolumn{2}{|r|}{ Mg. } & \multicolumn{2}{|c|}{$\%$ Total amino acid } \\
\hline & & & & Median & Range & Median & Range \\
\hline $\begin{array}{l}\text { Normal adults } \\
\text { Miscellaneous diseases } \\
\text { Rheumatoid arthritis } \\
\text { Collagen diseases } \\
\text { Children }\end{array}$ & $\begin{array}{r}8 \\
16 \\
16 \\
8 \\
16\end{array}$ & $\begin{array}{r}6 \mathrm{M}, 2 \mathrm{~F} \\
9 \mathrm{M}, 7 \mathrm{~F} \\
8 \mathrm{M}, 8 \mathrm{~F} \\
3 \mathrm{M}, 5 \mathrm{~F} \\
15 \mathrm{M}, 1 \mathrm{~F}\end{array}$ & $\begin{array}{r}22-74 \\
26-68 \\
17-67 \\
30-52 \\
5-14\end{array}$ & $\begin{array}{l}21.8 \\
21.1 \\
31.8 \\
33.5 \\
63.7\end{array}$ & $\begin{array}{l}14.9-33.0 \\
11.3-37.1 \\
13.0-62.3 \\
12.0-40.1 \\
38.4-126.3\end{array}$ & $\begin{array}{l}1.36 \\
1.74 \\
1.67 \\
1.78 \\
6.25\end{array}$ & $\begin{array}{l}0.94-2.12 \\
0.93-2.58 \\
0.60-3.41 \\
0.69-2.28 \\
2.96-9.28\end{array}$ \\
\hline
\end{tabular}

* The values presented are averages, usually of three separate 24 -hour collections.

ride), labeled with $\mathrm{I}^{1 \mathrm{~s}}$, and $0.4 \mathrm{ml}$. of a saturated sodium bicarbonate solution, vibrating for five minutes at $100^{\circ} \mathrm{C}$. The solution was then made acid with $0.3 \mathrm{ml}$. of $12 \mathrm{~N}$ hydrochloric acid and carbon dioxide removed. An appropriate amount of pipsyl hydroxyproline labelled with $\mathrm{S}^{\text {*6 }}$ was then added, and the solution was extracted with small portions of ether. The combined ether extract was washed with $0.2 \mathrm{~N}$ hydrochloric acid. The ether was then evaporated, the residue was taken up in a small volume of $2 \mathrm{~N}$ ammonium hydroxide, and then chromatographed on paper with n-amyl alcohol which had been previously shaken with $2 \mathrm{~N}$ ammonium hydroxide as the descending solvent. The hydroxyproline spot was eluted with ammonia, and the solution was acidified and extracted with ether. The ether extract was evaporated to a small volume, and applied to paper to be chromatographed with tetrachloroethane which had been previously shaken with $0.2 \mathrm{~N}$ hydrochloric acid as the descending solvent. Counting of the sulfur to iodine ratio in the purified hydroxyproline band was then carried out according to directions.

Satisfactory agreement was observed in the analysis of urine for total hydroxyproline between the Wiss method on the one hand and the isotopic derivative method and the modified ninhydrin method on the other, as shown in Table I. In all instances agreement between the Wiss and the other methods was within ten per cent.

When 1.0, 2.0, 3.0 and $4.0 \mathrm{mcg}$. of hydroxyproline were added to urine hydrolysates, $1.0,1.8,3.2$ and $3.6 \mathrm{mcg}$., respectively, were recovered.

Total urinary amino acid was determined by the ninhydrin method of Troll and Cannan (19).

Total nitrogen was determined by the Kjeldahl procedure.

Analysis of diet: The entire contents of the diet were collected for two days, and stirred thoroughly to provide a uniform suspension weighing 4,880 grams. A representative sample of $49.1 \mathrm{grams}$ of diet were mixed with $25 \mathrm{ml}$. of water, and $75 \mathrm{ml}$. of concentrated hydrochloric acid. The resulting suspension was hydrolyzed for three hours at 50 lbs. pressure. The hydrolysate was filtered, the water was removed by evaporation, the volume of the residue was made up to $25 \mathrm{ml}$. and analyzed by the Wiss method. The daily intake of total hydroxyproline determined in this way was $55 \mathrm{mg}$.
In some patients the effect of high meat diet and of gelatin, hydroxyproline, and proline supplements on the excretion of total hydroxyproline were determined.

\section{RESULTS}

\section{Excretion of free hydroxyproline}

In Table II are given the results obtained in normal adults. The median value of free hydroxyproline excreted daily in this group was $0.51 \mathrm{mg}$. (range, 0.26 to $0.79 \mathrm{mg}$.). The median value of total hydroxyproline excreted was $21.8 \mathrm{mg}$. (14.9 to $33.0 \mathrm{mg}$.). It is evident that the excretion of hydroxyproline in the free form was small in comparison with the total amount excreted, making up in this group only between two and three per

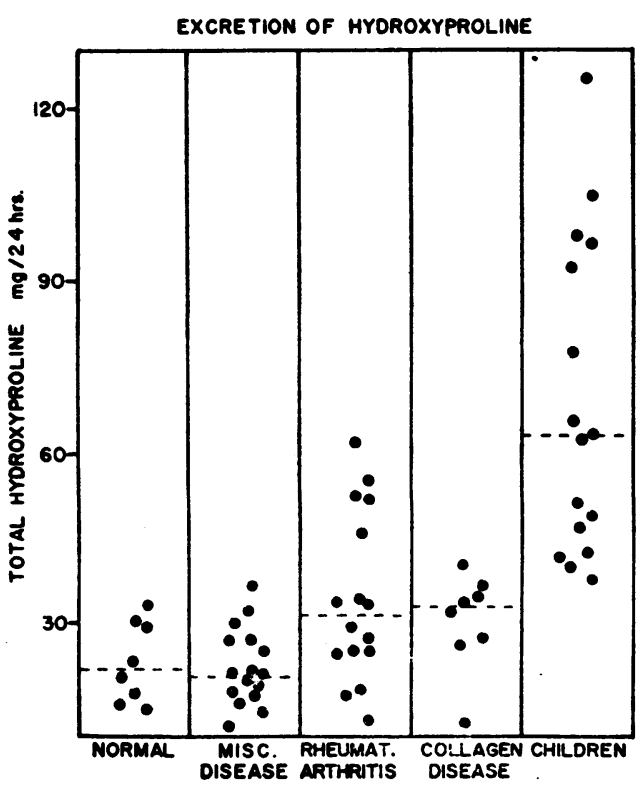

Fig. 1. Distribution of 24-Hour Excretion Values of Hydroxyproline in Various Categories 


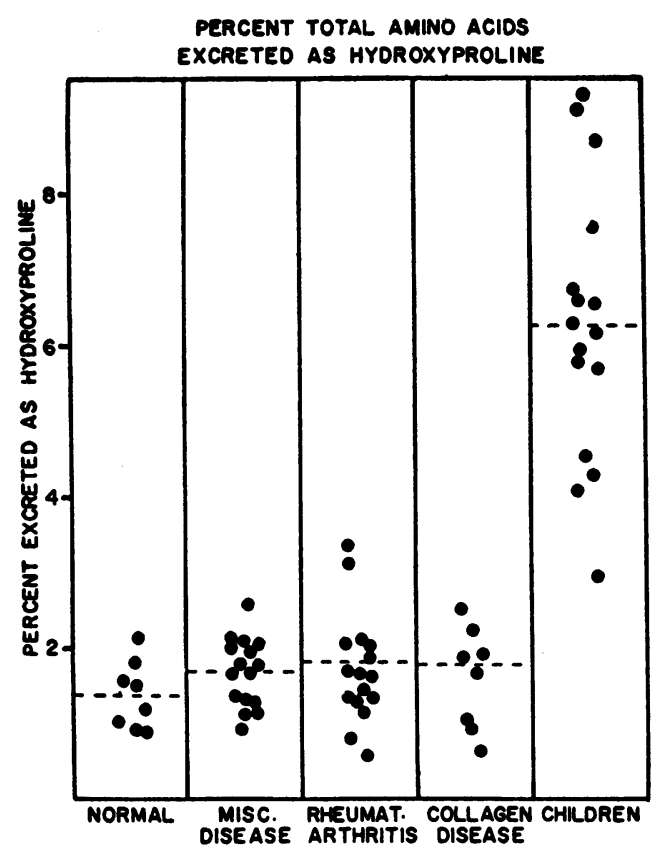

Fig. 2. Distribution of 24-Hour Excretion Values of Hydroxyproline Calculated as Per Cent of Total Amino Acid Excretion in the Various Categories

cent of the total excretion (average, 2.3 per cent; range 2.0 to 3.1 per cent). In four patients with rheumatoid arthritis, free hydroxyproline averaged 2.1 per cent (range, 1.3 to 4.5 per cent) of the total hydroxyproline excretion. In three patients with miscellaneous conditions, the corresponding value was 2.4 per cent (range, 1.2 to 3.7 per cent). In four children (one with minimal pulmonary tuberculosis, one convalescing from pneumococcal pneumonia, and two convalescing from rheumatic fever) the percentage was 2.0 (range, 0.97 to 4.9 per cent). In view of the small contribution of the free hydroxyproline to the total excretion, sub- sequent determinations were limited to total hydroxyproline.

\section{Excretion of total hydroxyproline}

The median daily excretion of total hydroxypro. line measured in eight normal adults (Table II) was $21.8 \mathrm{mg}$. (range, 14.9 to $33.0 \mathrm{mg}$.). It comprised 1.36 per cent (median value) of the total amino acid excreted daily. In sixteen adults with miscellaneous diseases, as indicated in Table III, the median daily excretion of total hydroxyproline was $21.1 \mathrm{mg}$. (range, 11.3 to $37.1 \mathrm{mg}$.). This was 1.74 per cent of the total hydroxyproline excretion. The median excretion in sixteen adults with active peripheral rheumatoid arthritis (Table III) was $31.8 \mathrm{mg}$. (range, 13.0 to $62.3 \mathrm{mg}$.). The per cent of total amino acid excreted in this form was 1.67. In eight adult patients with various collagen diseases, the median excretion of total hydroxyproline was $33.5 \mathrm{mg}$. (range, 12.0 to $40.1 \mathrm{mg}$.). The per cent of total amino acid excreted was 1.78.

Because of the difficulty of obtaining complete urine collections in young children, the figures for excretion presented in Table III are probably low, as borne out by reduced 24 -hour creatine and creatinine values (not reported here) and amino acid excretion values. Nevertheless, the level of excretion of total hydroxyproline measured was clearly higher than observed in the adult patients, the median figure being $63.7 \mathrm{mg}$. (range, 38.4 to $126.3 \mathrm{mg}$.). When the hydroxyproline excretion was calculated as per cent of total amino acid, the distinctly elevated median value of 6.25 per cent was obtained (range, 2.96 to 9.28 per cent). In the four children in whom the excretion of free hydroxyproline was measured, it was ascertained

TABLE IV

Effect of addition of four grams of 1(-)-hydroxyproline to low hydroxyproline diet on daily excretion of hydroxyproline (E. D., normal man, age 32)

\begin{tabular}{|c|c|c|c|c|c|}
\hline Day & Supplement & $\begin{array}{c}\text { Number of } \\
\text { divided } \\
\text { doses }\end{array}$ & $\begin{array}{c}\text { Total } \\
\text { hydroxy- } \\
\text { proline } \\
\text { (ms.) }\end{array}$ & $\begin{array}{l}\text { Total } \\
\text { amino } \\
\text { acid } \\
\text { (g.) }\end{array}$ & $\begin{array}{l}\text { \% Total } \\
\text { amino acid } \\
\text { as hydroxy- } \\
\text { proline }\end{array}$ \\
\hline $\begin{array}{l}1 \\
2 \\
3\end{array}$ & & & $\begin{array}{l}24.8 \\
26.8 \\
29.5\end{array}$ & $\begin{array}{l}1.91 \\
1.81 \\
2.06\end{array}$ & $\begin{array}{l}1.30 \\
1.47 \\
1.43\end{array}$ \\
\hline $\begin{array}{l}4 \\
5 \\
6\end{array}$ & $\begin{array}{l}\text { Hydroxyproline } \\
\text { Hydroxyproline } \\
\text { Hydroxyproline }\end{array}$ & $\begin{array}{l}1 \\
2 \\
4\end{array}$ & $\begin{array}{l}25.4 \\
27.6 \\
29.2\end{array}$ & $\begin{array}{l}1.79 \\
1.65 \\
1.62\end{array}$ & $\begin{array}{l}1.42 \\
1.67 \\
1.80\end{array}$ \\
\hline
\end{tabular}


that the elevation in hydroxyproline excretion was not due to an increase in the amount of free hydroxyproline excreted.

Because of the wide spread of the values in each group, only the median value and range of excretion have been presented, and further statistical treatment has not been considered advisable. The distribution of 24-hour excretion values of total hydroxyproline expressed directly and as per cent of total amino acid excreted is plotted in Figures 1 and 2, respectively, for the entire group of 64 patients in their separate categories.

\section{Effect of diet, dietary supplements and cortisone}

The addition of meat to the low hydroxyproline diet in the form of large meat servings at both lunch and dinner resulted in a small rise in the excretion of total hydroxyproline in a normal individual, i.e., from an average excretion of $26.9 \mathrm{mg}$. to $31.5 \mathrm{mg}$. daily. A similar experiment in a patient with a fracture of the tibia produced no increase in excretion. When four grams of $1(-)$ hydroxyproline, an amount about 80 times the measured content of the diet, were added to the low hydroxyproline diet of a normal individual in one, two, and four divided portions per twelve-hour period on three successive days, respectively, the excretion of hydroxyproline did not rise (Table IV). Similar results were obtained in three patients with rheumatoid arthritis and one with disseminated scleroderma. When four grams of proline were added to the low hydroxyproline diet of a patient with rheumatoid arthritis (Table V) and another with a healing fracture of the tibia, no significant increase in total hydroxyproline excretion occurred.
TABLE V

Effect of addition of four grams of $1(-)$-proline to low hydroxyproline diet on daily excretion of hydroxyproline

(G. I., male, rheumatoid arthritis, age 66)

\begin{tabular}{ccccc}
\hline \hline & $\begin{array}{c}\text { Total } \\
\text { hydroxy- } \\
\text { proline } \\
(\mathbf{m g .})\end{array}$ & $\begin{array}{c}\text { Total } \\
\text { amino } \\
\text { acid } \\
(\mathrm{g} .)\end{array}$ & $\begin{array}{c}\text { \% Total } \\
\text { amino } \\
\text { acid as } \\
\text { hydroxy- } \\
\text { proline }\end{array}$ \\
\hline 1 & Supplement & 29.4 & 2.11 & 1.39 \\
2 & & 29.6 & 2.99 & 1.01 \\
3 & Proline & 24.0 & 3.51 & 0.69 \\
4 & & 18.3 & 2.37 & 0.77 \\
5 & & 22.6 & 2.58 & 0.88 \\
\hline
\end{tabular}

When $200 \mathrm{mg}$. of cortisone were administered orally to one normal individual, two patients with rheumatoid arthritis, and one with scleroderma for periods of three to four days, no significant increase in the excretion of total hydroxyproline occurred or in the per cent of the total amino acid excreted as hydroxyproline.

In view of the lack of influence of administered free hydroxyproline or proline on the total urinary excretion of hydroxyproline, it was decided to determine whether the ingestion of bound hydroxyproline, in the form of gelatin, would increase the excretion of hydroxyproline. Accordingly, following two 24-hour control periods, 28 grams of gelatin, the equivalent of approximately four grams of hydroxyproline, were fed over a twelve-hour period in four divided portions to a normal subject and to a patient with rheumatoid arthritis. On the day on which the gelatin was administered a four and five fold increase, respectively (Table VI) in the total excretion of hydroxyproline took place in each. This was accompanied by an approximately 2.5 fold increase

TABLE VI

Effect of addition of 28 grams of gelatin to low hydroxyproline diet on daily excretion of total hydroxyproline in two subjects

\begin{tabular}{|c|c|c|c|c|c|c|}
\hline Subject & Diagnosis & Day & Supplement & $\begin{array}{c}\text { Total } \\
\text { hydroxy- } \\
\text { proline } \\
\text { (mg.) }\end{array}$ & $\begin{array}{c}\text { Total } \\
\text { amino } \\
\text { acid } \\
(\boldsymbol{g} .)\end{array}$ & $\begin{array}{l}\text { \% Total } \\
\text { amino acid } \\
\text { as hydroxy- } \\
\text { proline }\end{array}$ \\
\hline J.G. ఠ & Normal & $\begin{array}{l}1 \\
2 \\
3 \\
4\end{array}$ & Oral gelatin & $\begin{array}{r}27.4 \\
26.3 \\
134.0 \\
18.0\end{array}$ & $\begin{array}{l}2.34 \\
2.20 \\
4.41 \\
1.73\end{array}$ & $\begin{array}{l}1.17 \\
1.19 \\
3.04 \\
1.04\end{array}$ \\
\hline L. D. 9 & $\begin{array}{l}\text { Rheumatoid } \\
\text { arthritis }\end{array}$ & $\begin{array}{l}1 \\
2 \\
3 \\
4\end{array}$ & Oral gelatin & $\begin{array}{r}31.4 \\
29.0 \\
119.0 \\
36.5\end{array}$ & $\begin{array}{l}1.72 \\
1.42 \\
2.87 \\
2.00\end{array}$ & $\begin{array}{l}1.83 \\
2.02 \\
4.16 \\
1.83\end{array}$ \\
\hline
\end{tabular}


in each patient of the per cent of total amino acid excreted as hydroxyproline. On the following day, however, the excretion values had returned essentially to control levels.

\section{Acid hydrolysis of bound hydroxyproline of urine}

The stability of the bound hydroxyproline of urine was studied at varying concentrations of hydrochloric acid. Hydrolysis was carried out for 5.5 hours in sealed tubes at $50 \mathrm{lbs}$. pressure, and the per cent hydrolysis was calculated from the production of free hydroxyproline corrected for the amount of free hydroxyproline present in the urine at zero time. The per cent hydrolysis of the bound form under these conditions was 8.1 in $2 \mathrm{~N}$ acid and 52.0 in $4 \mathrm{~N}$, if calculated as 100 in $6 \mathrm{~N}$.

\section{Dialysis of bound hydroxyproline}

When a urine sample from a normal individual was dialyzed for 24 hours in cold running water, the concentration of free hydroxyproline fell from $0.59 \mathrm{mcg}$. per ml. to $0.19 \mathrm{mcg}$., and of the total hydroxyproline from $99.6 \mathrm{mcg}$. per $\mathrm{ml}$. to $9.1 \mathrm{mcg}$. Thus about ninety per cent of the total hydroxyproline was dialyzed. This would indicate that most, if not all, of the hydroxyproline of urine is in a dialyzable form.

\section{DISCUSSION}

Only analyses of total hydroxyproline are presented in the detailed studies since the average free hydroxyproline of urine did not exceed three per cent of the total excretion both in normal individuals and in patients with various diseases. The colorimetric method of Wiss for the analysis of total hydroxyproline, which has been employed in this study, was shown to be in agreement not only with the ninhydrin method of Troll and Cannan, but also with a highly reliable isotopic derivative method. Adult individuals were observed to excrete between 15 and $60 \mathrm{mg}$. of hydroxyproline daily. This was present almost entirely in a bound form, which was relatively stable in acid solution, and for the most part freely dialyzable, suggesting that it might be a low molecular weight peptide. Westall (20) has in fact recently offered good evidence for the presence of a peptide made up of equal parts of proline and hydroxyproline in normal human urine. This peptide showed about the same degree of stability in acid solution as observed in the present investigation in the case of the bound hydroxyproline complex. In agreement with our finding that hydroxyproline in the free state formed less than three per cent of the total amount excreted, is the failure of Westall to demonstrate free hydroxyproline in any of his chromatographic fractions.

The amount of total hydroxyproline excreted was not influenced by the oral ingestion of up to four grams of 1-hydroxyproline or 1-proline, although it was markedly increased by ingestion of equivalent amounts of these amino acids in the form of gelatin. The increment in urine hydroxyproline, however, represented only 2.5 per cent of the amount contained in the fed gelatin. One may surmise from the above observations that hydroxyproline in the free state is rapidly metabolized. Fed hydroxyproline when bound in peptide linkage, however, did at least in small quantities appear in the urine.

Since hydroxyproline is present only in collagen among the proteins of the body, except for the small amounts present in elastin, it is possible that the bound hydroxyproline of urine represents a peptide which is present in the collagen molecule. As such, its pool size and, therefore, presumably the quantity of it excreted could be related to synthesis and breakdown of collagen or one of its precursors. Evidence for the significant role of bound as opposed to free hydroxyproline in the natural synthesis of collagen may be found in the work of Stetten (21), who showed that when hydroxyproline, isotopically labeled with $\mathrm{N}^{15}$, was fed to rats it did not appear in the collagen, but that labeled hydroxyproline did appear in this protein after feeding of $\mathrm{N}^{15}$ labeled proline. These experiments would indicate that free hydroxyproline is not synthesized into collagen directly but rather that proline may first be converted to a peptide, in which state it is oxidized to hydroxyproline, and then incorporated into collagen. It should be mentioned in this connection, however, that the addition of four grams of proline to the diet of human subjects did not increase the total excretion of hydroxyproline in the present experiments. 
No apparent difference was observed in the levels of excretion of total hydroxyproline between normal adults and adults with miscellaneous diseases on the one hand, and patients with rheumatoid arthritis and collagen diseases on the other (Figures 1 and 2; Table III). This was true whether excretion of hydroxyproline was expressed directly or as per cent of total amino acid excreted. The median values in patients with rheumatoid arthritis and collagen diseases are somewhat higher than in the control groups, and the individual values tend to have a greater degree of scatter. On the other hand, the considerable overlap of values in all four groups suggests that the differences are not significant.

The lesions of the connective tissue in the rheumatic diseases and in hypersensitivity states are relatively focal in character (5-9), and the results of electron microscopic studies of tissue lesions obtained from patients with collagen diseases (10 12) and animals with hypersensitivity states (14) are divided in their conclusions as to whether collagen fibers are altered in these lesions. It would appear doubtful then that more than a small fraction of the total body collagen undergoes degradation at any given time as a result of disease, if this process occurs at all. On the other hand, if the normal collagen of the adult animal does not turn over (22), as discussed below, any contribution by altered collagen could provide significant amounts of hydroxyproline peptides.

The results obtained would at first glance suggest that either collagen is not broken down in rheumatoid arthritis and the collagen diseases, or if there is a process of collagen degeneration it is not sufficiently large in magnitude to increase the excretion of hydroxyproline. No definite conclusions can be drawn in this connection, however, because peptides of hydroxyproline resulting from the breakdown of collagen could well be subject to further metabolic degradation to free hydroxyproline and might, therefore, not appear in the urine, especially if available in only small amounts from focal lesions.

Neuberger, Perrone, and Slack (22) have established by administration of $\mathrm{C}^{14}$ labelled glycine to rats that the collagen of the adult animal does not incorporate glycine, although a small turnover has been observed by Robertson (23) in guinea pigs, on the basis of experiments with $\mathrm{N}^{15}$ labeled glycine. In young, growing rats, however, Neuberger, Perrone, and Slack did observe definite incorporation of labelled glycine indicating that some form of collagen does turn over in the growing animal. The observation (Table III, Figures 1 and 2) that the excretion of total hydroxyproline in children was two to three times greater than that of adults, and four to five times greater when calculated as per cent of total amino acid excreted, may be significant if considered in the light of the foregoing data on collagen turnover in growing rats. It raises for consideration two possibilities. One is that there is an increased pool of hydroxyproline peptide in children which is available for collagen synthesis, and that the observed increased excretion in children of bound hydroxyproline results from the presence of this increased pool. If this were so, the laying down of new collagen during growth would depend on the presence in the growing animal of a system capable of effecting more actively than in the adult the synthesis of one or more specific hydroxyproline peptides necessary for the formation of collagen.

A second possibility to explain the greater excretion of hydroxyproline in children, which may be linked to the preceding one, would be the presence in this age group of increased amounts of a soluble form of collagen, such as the alkali soluble collagen of Harkness, Marko, Muir, and Neuberger (24), and perhaps of acid soluble collagen (procollagen) (25). Alkali soluble collagen, which may be obtained in significant quantities only from young animals, has a definite solubility in body fluids at physiological $\mathrm{pH}$ since it is extractable from rabbit skin by neutral phosphate buffer (26). It has been shown by Harkness, Marko, Muir, and Neuberger to have a relatively high turnover rate, approaching that of the plasma proteins. The increment of bound hydroxyproline excreted by children might well represent peptides concerned with the metabolism of this soluble and therefore presumably circulating, metabolically active, form of collagen. It is worthy of note that greater excretion of bound hydroxyproline in children appeared to be characteristic of the younger age group in general and did not as far as could be told depend on the presence or ab- 
sence or on the activity of any particular disease process.

\section{SUMMARY}

1. Total urinary excretion of hydroxyproline was determined in patients with rheumatoid arthritis, collagen diseases, miscellaneous diseases, and in normal individuals, and in a group of children, both normal and with a variety of diseases.

2. Hydroxyproline was excreted almost entirely in a bound form, which was hydrolyzed appreciably only in $4 \mathrm{~N}$ acid or stronger, and which was freely dialyzable.

3. Ingestion of four grams of hydroxyproline and of proline did not increase the excretion of hydroxyproline. The excretion of hydroxyproline did rise, however, following ingestion of gelatin.

4. The median value of total hydroxyproline excreted daily in a group of eight normal adults was $21.8 \mathrm{mg}$. (range 14.9 to $33.0 \mathrm{mg}$.). Free hydroxyproline represented between two and three per cent of the total.

5. There was no significant difference in the excretion of total hydroxyproline in the groups of normal individuals, patients with miscellaneous diseases, rheumatoid arthritis, and collagen diseases, either on an absolute basis or when expressed as per cent of total amino acid.

6. The excretion of total hydroxyproline in a miscellaneous group of children was two to three times greater than that of the adult groups. When expressed as per cent of total amino acid, it was three to 4.5 times as great. This increased excretion did not appear to be related to the presence or absence of disease. It is suggested that it may reflect the presence of increased quantities in the younger age group of a circulating and metabolically active form of collagen, such as alkali soluble collagen.

\section{ACKNOWLEDGMENT}

The authors wish to acknowledge the help of Mr. Alfred Smith, Mrs. Jennie Shatton, Mrs. Dorothy Skupp, and Mrs. Ina Rubenstein.

\section{REFERENCES}

1. Bowes, J. H., Elliott, R. G., and Moss, J. A., Some differences in the composition of collagen and extracted collagens and their relation to fibre forma- tion and dispersion in Nature and Structure of Collagen, Randall, J. T., Ed., New York, Academic Press, 1953.

2. Neuman, R. E., and Logan, M. A., The determination of hydroxyproline. J. Biol. Chem., 1950, 184, 299.

3. Neuman, R. E., and Logan, M. A., The determination of collagen and elastin in tissues. J. Biol. Chem., 1950, 186, 549.

4. Ziff, M., Kantor, T., Bien, E., and Smith, A., Studies on the composition of the fibrinoid material of the subcutaneous nodule of rheumatoid arthritis. J. Clin. Invest., 1953, 32, 1253.

5. Klinge, F., Der Rheumatismus, pathologisch-anatomische und experimentell-pathologische Tatsachen und ihre Auswertung für das ärztliche Rheumaproblem. Ergebn. d. allg. Path. u. path. Anat., 1933, 27, 1.

6. Bahrmann, E., Uber die fibrinoide Degeneration des Bindegewebes. Virchows Arch. f. path. Anat., 1937, 300, 342.

7. Arthus, M., and Breton, M., Lésions cutanées produites par les injections de sérum de cheval chez le lapin anaphylactisé par et pour ce sérum. Compt. rend. Soc. de biol., 1903, 55, 1478.

8. Gerlach, W., Studien über hyperergische Entzündung. Virchows Arch. f. path. Anat., 1923, 247, 294.

9. Rich, A. R., Hypersensitivity in disease, with especial reference to periarteritis nodosa, rheumatic fever, disseminated lupus erythematosus and rheumatoid arthritis. Harvey Lect., 1946-1947, 42, 106.

10. Gross, J., In vitro fibrogenesis of collagen in Conference on Metabolic Interrelations, Trans. Josiah Macy, Jr. Fdn. Conf., 1952, 4, 32.

11. Gale, J. C., Electron microscope studies of collagen from normal and diseased tissues. Am. J. Path., 1951, 27, 455.

12. Wolpers, C., Elektronmikroskopische Untersuchungen zur Pathologie Kollagener Fasern. Frank. Zeit. f. Path., 1950, 61, 417.

13. Kellgren, J. H., Ball, J., Astbury, W. T., Reed, R., and Beighton, E., Biophysical studies of rheumatoid connective tissue. Nature, 1951, 168, 493.

14. Rich, A. R., Voisin, G. A., and Bang, F. B., Electron microscopic studies of the alteration of collagen fibrils in the Arthus phenomenon. Bull. Johns Hopkins Hosp., 1953, 92, 222.

15. Folin, $\mathrm{O}$., and $\mathrm{Wu}, \mathrm{H}$., A system of blood analysis. J. Biol. Chem., 1919, 38, 98.

16. Wiss, O., Uber eine Mikrobestimmung des Oxyprolins in Blut und Harn; Beeinflussung des Oxyprolin-Gehaltes durch Verabreichung von Prolin. Helvet. chim. acta, 1949, 32, 149.

17. Keston, A. S., Udenfriend, S., and Levy, M., Determination of organic compounds as isotopic derivatives. II. Amino acids by paper chromatographic and indicator techniques. J. Am. Chem. Soc., 1950, 72, 748.

18. Rogers, C. J., Kimmel, J. R., Hutchin, M. E., and Harper, H. A., A hydroxyproline method of analy- 
sis for a modified gelatin in plasma and urine. $\mathrm{J}$. Biol. Chem., 1954, 206, 553.

19. Troll, W., and Cannan, R. K., A modified photometric ninhydrin method for the analysis of amino and imino acids. J. Biol. Chem., 1953, 200, 803.

20. Westall, R. G., The amino acids and other ampholytes of urine. 3. Unidentified substances excreted in normal human urine. Biochem. J., 1955, 60, 247.

21. Stetten, M. R., Some aspects of the metabolism of hydroxyproline studied with the aid of isotopic nitrogen. J. Biol. Chem., 1949, 181, 31.

22. Neuberger, A., Perrone, J. C., and Slack, H. G. B., The relative metabolic inertia of tendon collagen in the rat. Biochem. J., 1951, 49, 199.
23. Robertson, W. van B., Influence of ascorbic acid on $\mathrm{N}^{23}$ incorporation into collagen in vivo. J. Biol. Chem., 1952, 197, 495.

24. Harkness, R. D., Marko, A. M., Muir, H. M., and Neuberger, A., The metabolism of collagen and other proteins of the skin of rabbits. Biochem. J., 1954, 56, 558.

25. Orekhovitch, V. N., Toustanovski, A. A., Orekhovitch, K. D., and Plotnikova, N. E., The procollagen of hide. Biokhimiya, 1948, 13, 55.

26. Jackson, D. S., and Fessler, J. H., Isolation and properties of a collagen soluble in salt solution at neutral pH. Nature, 1955, 176, 69.

\section{SPECIAL NOTICE TO SUBSCRIBERS}

Post Offices will no longer forward the Journal when you move.

Please notify The Journal of Clinical Investigation, Business Office, 622 West 168th Street, New York 32, N. Y. at once when you have a change of address, and do not omit the zone number if there is one. 